\title{
Monitoring of fecal contamination in a partly restored urban stream in Seoul, Korea
}

\author{
Eun-Young Seo ${ }^{1}$, Dawoon Jung ${ }^{1}$, Seung-Cheon Yong', Rho Young Park ${ }^{1}$, Young-Ok Lee ${ }^{2^{+}}$, \\ Tae-Seok $\mathrm{Ahn}^{{ }^{+}}$ \\ ${ }^{1}$ Department of Environmental Science, Kangwon National University, Chuncheon, Republic of Korea \\ ${ }^{2}$ Depatment of Biological Science, Daegu University, Gyeongsan, Republic of Korea
}

\begin{abstract}
Cheonggye-cheon is a partly restored urban stream located in central Seoul. We monitored fecal contamination using three different fecal indicators, total coliforms (TC), fecal coliforms (FC) and E. coli, to assess differences in each indicator on days of varying weather conditions. Presumptive TC, FC and E. coli colonies were identified by their $16 \mathrm{~S}$ rRNA sequences. The results showed that enumeration of E. coli provided a better reflection of fecal contamination of the stream than TC and FC. The main sources of contamination were the inflow of fecal-polluted groundwater from the vicinity of a subway line and two inflowing streams. The fecal contamination was worsened on days with heavy rain because untreated sewage from a collecting facility flowed into the stream. Moreover, growth potential of fecal indicator $(E$. coli) in situ induced by algal exudates was measured. Our results suggest that an appropriate standard based on E. coli rather than TC and FC should be established for improving water quality management strategies of Cheonggye-cheon in the future.
\end{abstract}

Keywords: Escherichia coli, Fecal contamination, Microbial water quality, Urban stream

\section{Introduction}

Cheonggye-cheon is a partly restored urban stream flowing through central Seoul, the capital of Korea. The stream was originally fed by tributaries draining the mountainous areas in the upper watershed [1], but the stream became severely polluted during the modernization of Seoul, especially the discharge of untreated sewage to Cheonggye-cheon. Between 1967 and 1971, Cheonggye-cheon was covered and placed underground similar to sewer lines, and roads and bridges were constructed as the area along the stream became a symbol of modernization and industrialization [2]. During 2003 to 2005, the Cheonggye-cheon watershed was the target of a major restoration project and the stream itself was uncovered and partly restored. The stream now carries water that has been disinfected (UV treatment) by the Seoul public water supply system. After restoration, some studies found increased diversity in stream flora and fauna in Cheonggye-cheon as well as an increase in the number of visitors who wade along the stream and/or sometimes soak their feet in the stream [3]. Therefore there has been heightened citizen awareness and interest in water quality and safety [4]. Some reports have shown that the water quality criteria as assessed using fecal indicator bacteria levels exceed water quality standards especially on rainy days, and consequently some uses of Cheonggye-cheon are prohibited on rainy days [5].

In natural stream ecosystems, it is well known that rainfall can adversely affect water quality [6]. The concentration of fecal indicator such as E. coli and Enterococcus during rain events was increased greatly compared to that at time of dry weather conditions and the intensity varied depending on the several hydrographical factors [6]. A number of physico-chemical factors associated with rain events in a watershed usage can impact tributaries and affect the microbial water quality in streams $[7,8]$. To evaluate the risk to humans, microbiological standards for water quality have been developed and used in many countries [9]. Fecal indicator organisms, including total coliforms (TC), fecal coliforms (FC) and Escherichia coli, are used world-wide to assess the degree of fecal contamination, because high populations of fecal indicators may indicate a risk to human health risk, although there are questions regarding the usefulness of some indicators[10, 11]. In general, there have been few studies with a focus on microbial water quality in urban streams.

In one study in Cheonggye-cheon which was conducted for
This is an Open Access article distributed under the terms of the Creative Commons Attribution Non-Commercial License (http://creativecommons. org/ licenses/by-nc/3.0/) which permits unrestricted non-commercial use, distribution, and reproduction in any medium, provided the original work is properly cited.
Received May 11, 2015 Accepted March 23, 2016

${ }^{\dagger}$ Corresponding author

Email: ahnts@kangwon.ac.kr, ecolomi@daegu.ac.kr Tel: +82-53-850-6456 Fax: +82-53-850-6459

Copyright (C) 2016 Korean Society of Environmental Engineers 
only one month (November), fecal contamination increased dramatically from midstream to downstream, probably due to the inflow from tributaries and unknown non-point source pollutants, even though the water in Cheonggye-cheon is mostly disinfected water [5]. This study aimed to assess the microbial water quality of the partly restored Cheonggye-cheon stream using several fecal indicators. We specifically monitored three commonly used indicators of fecal pollution and quantified changes in the indicators following rain events. We also investigated the growth potential of fecal indicators associated with algal exudates in situ. Some suggestions for improving water quality management strategies in Cheonggye-cheon are discussed.

\section{Materials and Methods}

\subsection{Sample Collections}

Water samples were collected from Cheonggye-cheon and two inflowing tributaries on April 24 (immediately following a three-day rain event), May 6 and June 11 (days without rainfall). The sampling sites were an upstream station (St. 1; Mojeongyo), mid-stream (St. 2; Ogansugyo), down-stream (St. 5; Yongdap station), two confluence sites (St. 3; Seongbuk-cheon confluence, St. 4; Jeongneung-cheon confluence) and two inflowing streams (St. 6; Seongbuk-cheon, St. 7; Jeongneung-cheon). In order to evaluate the effect of rainfall on fecal contamination, water samples were collected at four sites (St. 1, St. 8; Muhakgyo, St. 9; Jungnang-cheon and St. 10; a sewage collecting facility) (Fig. 1). These water samples were collected on a rainy day (July 5) and $24 \mathrm{~h}$ later (July 6). Samples were collected aseptically in sterilized $1 \mathrm{~L}$ bottles from a water depth of $30 \mathrm{~cm}$. To assess the density of fecal indicator (E. coli) attached on substrates such as green algae (Spirogyra sp.), stems and roots of macrophyte (Phragmites sp.) and sediment sample were collected aseptically in sterilized $50 \mathrm{~mL}$ conical bottles. All samples were stored at $4^{\circ} \mathrm{C}$, and triplicates per sample were analyzed within $6 \mathrm{~h}$ after sampling and the mean values and standard deviation were compared.

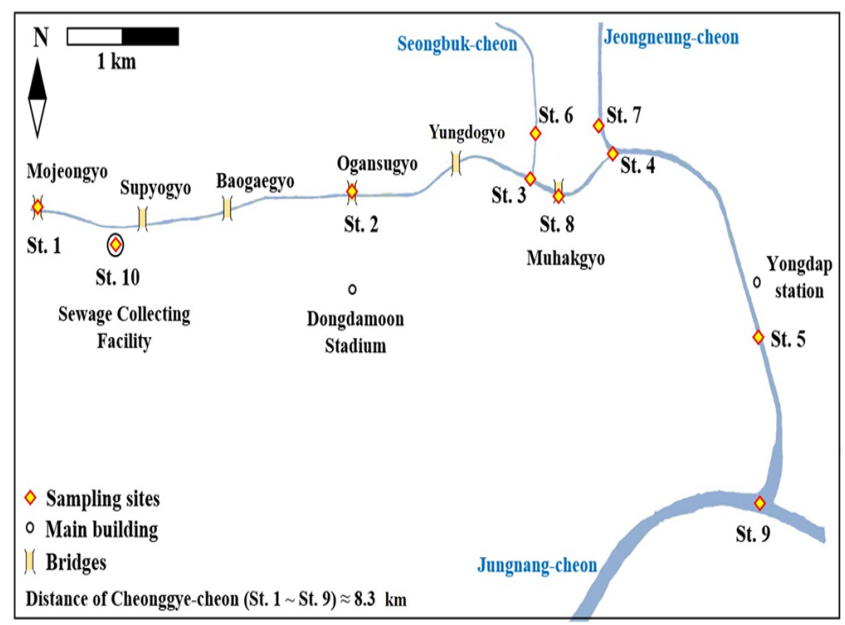

Fig. 1. Map of sampling sites in Cheonggye-cheon.

\subsection{Detection of Fecal Indicators from Water Samples}

Total coliforms (TC), fecal coliforms (FC) and E. coli were detected using Coliliert-18 kits (IDEXX, Ludwigsburg, Germany) using the most probable number (MPN) method, according to the manufacturer's instructions. Briefly, $100 \mathrm{~mL}$ of the water samples was mixed with a reagent in the vessel until the reagent completely dissolved. Quanti-Tray ${ }^{\circledR}$ bags with samples for all fecal indicators were then incubated and assayed. The enumeration of TC and E. coli was carried out using the same Quanti-Tray ${ }^{\circledR}$ bag under incubation at $35.5 \pm 0.5^{\circ} \mathrm{C}$ for $24 \mathrm{~h}$. After the quantification of TC, the E. coli was assayed using UV GL 25 (CA, USA). For detection of FC, the Quanti-Tray ${ }^{\circledR}$ bags with samples were incubated at $44.5^{\circ} \mathrm{C}$ for $22-24 \mathrm{~h}$ after pre-incubation at $35^{\circ} \mathrm{C}$ for $2 \mathrm{~h}$. Each sample was tested in triplicate and the mean values and standard deviation were compared.

\subsection{Density of $E$. coli Attached on Substrates}

To detach E. coli from "Spirogyra sp. stems" and "roots of Phragmites" and "sediment", samples were prepared by placing $1 \mathrm{~g}$ of each substrate in a stomacher bag with $20 \mathrm{~mL}$ of PBS and treating the bags with Stomacher 400 (Seward Medical, United Kingdom) at the maximum speed for $15 \mathrm{~min}$. The debris in suspension was removed by centrifugation at 3,000 $\mathrm{xg}$ at room temperature for $15 \mathrm{~min}$. Ten milliliters of each supernatant was filtered onto a cellulose nitrate filter (25-mm diameter, 0.45 um poresize; Whatman, United Kingdom). After filtration, the membrane was placed on a modified m-TEC agar and incubated at $44.5 \pm 0.5^{\circ} \mathrm{C}$ for $22 \pm 2 \mathrm{~h}$ after pre-incubation at $35.5 \pm 0.5^{\circ} \mathrm{C}$ for $2 \pm 0.5$ $\mathrm{h}$ [12]. To evaluate the growth potential for $E$. coli, an experiment with two sets was performed as follows. In every set, E. coli (IMSNU 10085) was completely mixed with $1 \mathrm{~L}$ of unpolluted upstream water. The concentration of $E$. coli at the beginning point $(0 \mathrm{~h})$ of the experiment was $30 \pm 1$ and $32 \pm 1 \mathrm{CFU} / \mathrm{mL}$, respectively, as evaluated by m-TEC agar. A fraction of Spirogyra sp. (10 g wet weight) was added to one set, but not to the other (control). The sets were incubated at the temperature of the stream water $\left(12^{\circ} \mathrm{C}\right)$ for $72 \mathrm{~h}$. To evaluate the change of the density of $E$. coli, aliquots of water from the two experimental set-ups were sampled every $12 \mathrm{~h}$. The number of E. coli colonies was enumerated using $\mathrm{m}$-TEC agar. The $12 \mathrm{~h}$ interval time was used because the stream flow from the upstream station (St. 1) to the down-stream station (St. 9) in the restored zone of Cheonggye-cheon took about $8 \mathrm{~h}$ according to the results of a preliminary study.

\subsection{False Positive E. coli Assay by $16 \mathrm{~S}$ rRNA Gene Retrieval}

In order to evaluate the accuracy of the presumptive fecal indicators (TC, FC and E. coli), some of the corresponding colonies grown on MPN tubes were sub-cultured on selective media - m-Endo agar Les for TC, m-FC agar for FC, and m-TEC agar for E. coli - and then DNA was extracted from the colonies for further identification using 16S rRNA gene sequences. Extracted DNA was used directly as a template for PCR. 16S rRNA gene was amplified using the universal primers 27F (5'-AGAGTTTGATCCTGGC TCAG-3') and 1492R (5'-GGTTACCTTGTTACGACTT-3') with a hot start taq system (Takara, Japan). The purified PCR products were sequenced with a commercial sequencer (Macrogen, Korea). 
The partial sequences of 550 to 750 long fragments were compared with sequences data from GenBank (http:// blast.ncbi.nih.gov/) to identify the closest matching sequences.

\section{Results}

\subsection{Variation of Fecal Indicators in the Restored Area}

The density of TC, FC and E. coli had a tendency to increase from St. 1 to St. 4, reaching maximum densities after the merging of the two tributary streams (Fig. 2a, 2b and 2c). Fecal contamination decreased about $2 \mathrm{~km}$ downward, at St. 5. In addition, the densities of all the determined fecal indicators, especially TC, was over 10 times higher immediately after a three-day long rainfall $\left(24^{\text {th }}\right.$ April) than on days of ordinary weather in May and June. Synthetically considering all data regardless of the sampling sites, the number of TC $(5-24,196 \mathrm{MPN} / 100 \mathrm{~mL})$ and FC $(<1-19,081$ MPN/100 mL) fluctuated largely depending on the sampling date, while $E$. coli showed a relatively narrow range of variation (< 1-728 MPN/100 mL).

During all collection time, E. coli was not detected in samples from St. 1. Only TC was detected, but at very low levels $(5 \pm$ $0-33 \pm 5 \mathrm{MPN} / 100 \mathrm{~mL})$. The numbers of both TC (52 $\pm 1-9,652$ $\pm 45 \mathrm{MPN} / 100 \mathrm{~mL})$ and FC $(19 \pm 3-668 \pm 9 \mathrm{MPN} / 100 \mathrm{~mL})$ increased significantly at St. 2. However, the density of $E$. coli was lower, from less than 1 to $196 \pm 1 \mathrm{MPN} / 100 \mathrm{~mL}$. At the downstream sites after the confluence with the inflowing tributaries (St. 3 and 4), the densities of all fecal bacteria increased, especially on the rainy day (24 $4^{\text {th }}$ of April, Fig. 2a). On the rainy day, the density of $E$. coli reached the peak values of $728 \pm 23 \mathrm{MPN} / 100 \mathrm{~mL}$ (St. 3) and $630 \pm 22 \mathrm{MPN} / 100 \mathrm{~mL}$ (St. 4), but decreased to $288 \pm$ $13-289 \pm 10 \mathrm{MPN} / 100 \mathrm{~mL}$ (St. 3) and $151 \pm 2-279 \pm 3 \mathrm{MPN} / 100$ $\mathrm{mL}$ (St. 4) on days without rain $\left(6^{\text {th }}\right.$ May and $11^{\text {th }}$ June) respectively (Fig. 2b, 2c). At the tributary stream sites, St. 6 and 7, high densities of both TC (more than 24,196 MPN/100 mL at both sites) and FC (St. 6; 8,217 \pm 70 MPN/100 mL, St. 7; 19,018 \pm 1,463 MPN/100 $\mathrm{mL}$ ) were detected on the rainy day (24 $4^{\text {th }}$ April). The density of E. coli was comparatively low (St. 6; $417 \pm 5 \mathrm{MPN} / 100 \mathrm{~mL}$, St. 7; $476 \pm 8 \mathrm{MPN} / 100 \mathrm{~mL}$ ), lower than those at the confluent sites in the main stream (St. 3 and 4). On the two days without rain, all of the determined fecal indicators at St. 6 (TC: $1,327 \pm 63-1,745$ $\pm 41 \mathrm{MPN} / 100 \mathrm{~mL}$; FC: $153 \pm 1-547 \pm 28 \mathrm{MPN} / 100 \mathrm{~mL}$; E. coli $50 \pm 2-134 \pm 2 \mathrm{MPN} / 100 \mathrm{~mL}$ ) varied similarly, but were a little higher than those at St. 7 (TC: $738 \pm$ 42-3,522 $\pm 114 \mathrm{MPN} / 100$ $\mathrm{mL}$; FC: $261 \pm 13-251 \pm 3 \mathrm{MPN} / 100 \mathrm{~mL}$; E. coli: $50 \pm$ 1-121 $\pm 1 \mathrm{MPN} / 100 \mathrm{~mL})$.

The density of TC, FC and E. coli at St. 5 was significantly lower on the sampling dates without rain (May 6 and June 11), even though it is located about $2 \mathrm{~km}$ down from the merging of the severely polluted tributary stream (St. 7), maybe due to the dilution effect. The density of $E$. coli on the sampling date without rain in May and June was not detected $(<1 \mathrm{MPN} / 100$ $\mathrm{mL}$ ), but the density on day of immediately after the three day long rainfall (April 24) was relatively high (30 $\pm 1 \mathrm{MPN} / 100 \mathrm{~mL})$ as seen in Figs. 2a, 2b and 2c. This shows that the microbial water quality in Cheonggye-cheon is heavily affected by rain events.
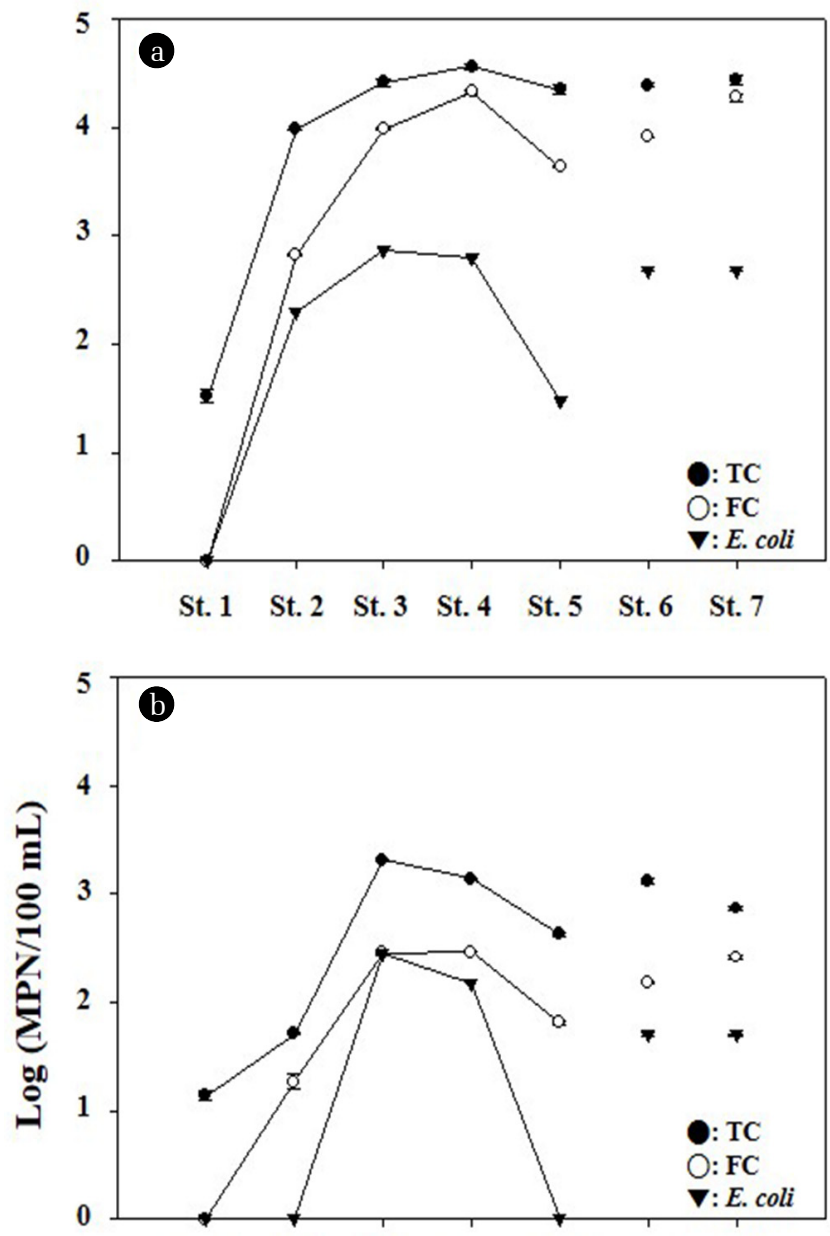

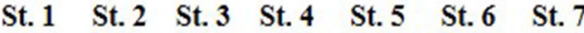

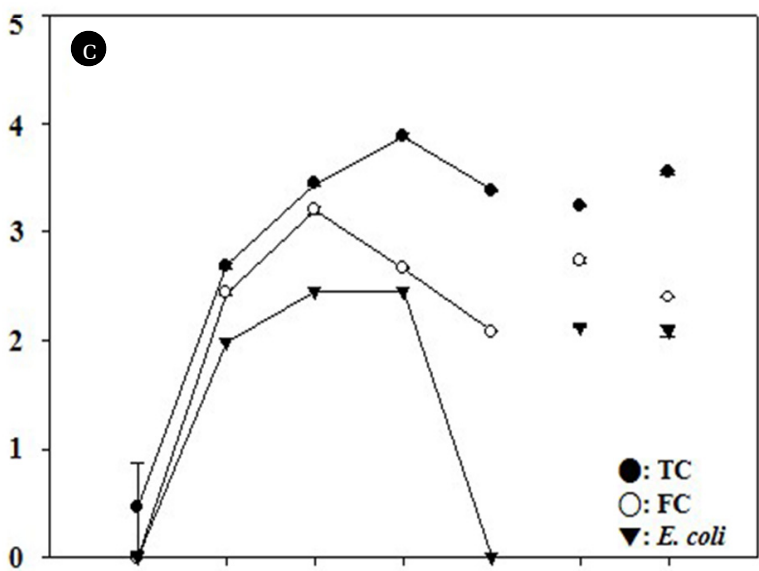

$\begin{array}{lllllll}\text { St. } 1 & \text { St. } 2 & \text { St. } 3 & \text { St. } 4 & \text { St. } 5 & \text { St. } 6 & \text { St. } 7\end{array}$

\section{Sites}

Fig. 2. Variations of fecal indicators at sampling sites (St.1-5; main stream, St.6-7; tributary stream) on a sampling date (2a; on 24th April after rainfall $57 \mathrm{~mm} / 3$ days, $2 \mathrm{~b}$ and $2 \mathrm{c}$; days of ordinary weather on 6th May and 11th June, respectively). 
Table 1. The Effect of Rainfall on the Density of TC, FC and E. coli (MPN/100 mL)

\begin{tabular}{|c|c|c|c|c|}
\hline Date & Sites & $\begin{array}{l}\text { Total Coliforms } \\
\text { (MPN/100 mL) }\end{array}$ & $\begin{array}{l}\text { Fecal Coliforms } \\
\text { (MPN/100 mL) }\end{array}$ & $\begin{array}{c}\text { E. coli } \\
\text { (MPN/100 mL) }\end{array}$ \\
\hline \multirow{3}{*}{$\begin{array}{c}5^{\text {th }} \text { July, } 2012 \\
\text { (rain fall } 72 \mathrm{~mm} / \text { day) }\end{array}$} & St. 1 & $4,500 \pm 40$ & $1,850 \pm 70$ & $1,080 \pm 20$ \\
\hline & St. 8 & $92,060 \pm 1,550$ & $10,390 \pm 210$ & $1,870 \pm 10$ \\
\hline & St. 9 & $60,190 \pm 2,790$ & $9,870 \pm 30$ & $1,480 \pm 0$ \\
\hline \multirow{3}{*}{$\begin{array}{l}6^{\text {th }} \text { July, } 2012 \\
\text { (after } 24 \text { hours) }\end{array}$} & St. 1 & $5,227 \pm 277$ & $370 \pm 2$ & $170 \pm 3$ \\
\hline & St. 8 & $86,680 \pm 1,101$ & $3,360 \pm 0$ & $980 \pm 25$ \\
\hline & St. 9 & $77,377 \pm 5,419$ & $7,940 \pm 330$ & $2,430 \pm 28$ \\
\hline
\end{tabular}

\subsection{The Effect of Rainfall on Water Quality of Cheonggye- cheon}

The density of indicators on the rainy day (5th of July 2012) was much higher than those on the sampling dates without rain (Table 1). The density of E. coli at St. 1 and St. 8 was very high due to the overflow phenomenon of untreated sewage (St.1; $1,080 \pm 20 \mathrm{MPN} / 100 \mathrm{~mL}$ St.8; 1,870 $\pm 10 \mathrm{MPN} / 100 \mathrm{~mL}$ ), contrary to the result at St.1 showing no $E$. coli on the no rainy sampling dates. After $24 \mathrm{~h}$, the number of $E$. coli decreased sharply, especially at St. $1(170 \pm 3 \mathrm{MPN} / 100 \mathrm{~mL})$, compared to that at St. $8(980 \pm 25 \mathrm{MPN} / 100 \mathrm{~mL})$. This implies that the unidentified source of fecal pollution around the stream was diluted and flowed into the stream over the entire waterway. However, an opposite phenomenon occurred at St. 9. The number of E. coli enumerated on the rainy day $(1,480 \pm 0 \mathrm{MPN} / 100 \mathrm{~mL})$ increased $24 \mathrm{~h}$ later $(2,430 \pm 28 \mathrm{MPN} / 100 \mathrm{~mL})$ at St. 9 maybe due to longer hydrological retention time compared to the watershed of St. 1.-8.

\subsection{Regrowth Potential of $E$. coli in Cheonggye-cheon}

The number of E. coli attached on Spirogyra sp. varied from 110 $\pm 15-880 \pm 102 \mathrm{CFU} / \mathrm{g}$, with an average of $175.2 \pm 98 \mathrm{CFU} / \mathrm{g}$. The number of $E$. coli attached on the roots and stems of Phragmites sp. was also enumerated. Compared to the roots (234 $\pm 32 \mathrm{CFU} / \mathrm{g})$, the number of $E$. coli on stems was larger (950 $\pm 89 \mathrm{CFU} / \mathrm{g})$, possibly due to the concentration of exudates derived from both algae and macrophyte stems, and the increased surface area on which to attach. The number of $E$. coli in sediment $(200 \pm 23$ CFU/g) was similar with the population on the roots of Phragmites sp., which was rooted in sediment, as these two substrates were taken from the same sediment environment.

The number of $E$. coli in the presence of algae increased from $32 \pm 1$ to $44 \pm 3 \mathrm{CFU} / \mathrm{mL}$ over the first $12 \mathrm{~h}$ of exposure at the same water temperature $(p=0.002)$, and then decreased gradually to $16 \pm 3 \mathrm{CFU} / \mathrm{mL}$ at $72 \mathrm{~h}$. In contrast, the density of $E$. coli without algae did not increase $(p=0.101)$, and was in steady state or decreased. The value of $E$. coli was $30 \pm 1 \mathrm{CFU} / \mathrm{mL}$ at $0 \mathrm{~h}$, and was finally $19 \pm 1 \mathrm{CFU} / \mathrm{mL}$ after $72 \mathrm{~h}$ of exposure (Fig. 3). Taken all together, the growth potential of fecal indicator (E. coli) in situ due to exudates by algae and plant was observed but not enough to affect.

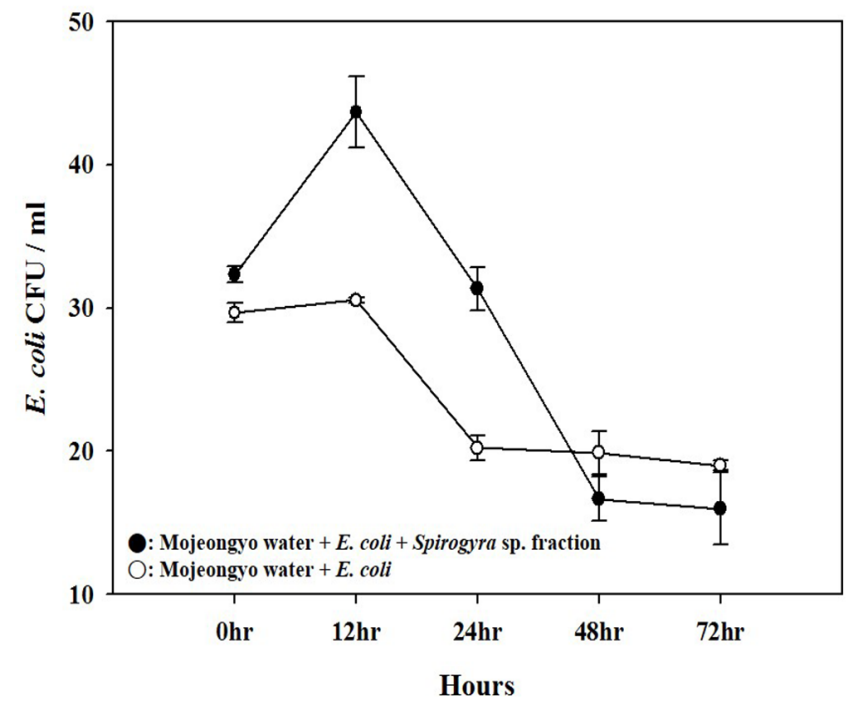

Fig. 3. Changes of presumptive colonies of $E$. coli grown with and without Spirogyra sp. fraction.

\subsection{How Accurate Are the Fecal Indicators?}

From a total of 50 colonies presumed to be TC colonies (10), FC colonies (20) and E. coli colonies (20) from isolates on the corresponding selective media using the Colilert-18 system, 16S rRNA genes were extracted, sequenced, and identified by comparison to the sequences of those in databases in GenBank (Table 2). All the retrieved presumptive TC colonies on m-Endo agar Les media belonged to taxonomic order, Aeromonadales and Enterobacteriales. However, on genus level, 4 of them was Aeromonas sp., regarded as non-fecal indicator and any colony was not closely related to E. coli. Also, 20 presumptive FC colonies grown on m-FC agar were all related to enteric bacteria (Citrobacter sp., Enterobacter sp., Escherichia coli, Escherichia sp., Klebsiella sp. and Shigella sp.), but 11 sequences of 20 colonies were identified as Klebsiella sp. which occurred also in non-fecal environment $[13,14]$. By contrast, 14 colonies from 20 presumptive E. coli colonies on m-TEC agar media were identified as E. coli, which is regarded as best fecal indicator [10, 11]. This implies that among the fecal indicators, the enumeration of $E$. coli reflected the real fecal polluted state of the stream better than those of TC and FC. 
Table 2. Phylogenetic Affiliations of 50 Colonies Judged as Presumptive TC (10), FC (20) and E. coli (20) Grown on Corresponding Selective Media from the Isolates by the Colilert-18 System Based on 16S rRNA Gene Sequences

\begin{tabular}{|c|c|c|c|c|c|}
\hline Medium & $\begin{array}{l}\text { Taxonomic group } \\
\text { (order) }\end{array}$ & Closet species & $\begin{array}{c}\text { Similarity } \\
\%\end{array}$ & $\begin{array}{l}\text { Accession } \\
\text { No. }\end{array}$ & $\begin{array}{c}\text { Isolates } \\
\text { No. }\end{array}$ \\
\hline \multirow{8}{*}{ m-Endo } & \multirow{3}{*}{ Aeromonadales } & Aeromonas caviae & 99 & KC622033 & 1 \\
\hline & & Aeromonas hydrophila & 98 & KC793902 & 2 \\
\hline & & Aeromonas salmonicida & 98 & KF364949 & 1 \\
\hline & \multirow{5}{*}{ Enterobacteriales } & Enterobacter sp. & 98 & HM161865 & 1 \\
\hline & & Escherichia fergusonii & 98 & HE612113 & 1 \\
\hline & & Klebsiella $s p$ & 98 & HF548460 & 1 \\
\hline & & Raoultella planticola & 99 & HF562905 & 2 \\
\hline & & Serratia sp. & 99 & КС306405 & 1 \\
\hline \multirow{10}{*}{$\mathrm{m}-\mathrm{FC}$} & \multirow{10}{*}{ Enterobacteriales } & Citrobacter freundii & 99 & AB548824 & 1 \\
\hline & & Enterobacter ludwigii & 99 & KJ748609 & 2 \\
\hline & & Escherichia coli & 99 & KC835104 & 1 \\
\hline & & Escherichia fergusonii & 99 & KJ803903 & 2 \\
\hline & & Klebsiella pneumoniae & $99-100$ & KC835115 & 6 \\
\hline & & & $99-100$ & СР009114 & 2 \\
\hline & & Klebsiella sp. & $99-100$ & KJ803930 & 3 \\
\hline & & Shigella flexneri & 99 & KM035402 & 1 \\
\hline & & & 99 & KC835130 & 1 \\
\hline & & Shigella sonnei & 98 & KJ023317 & 1 \\
\hline \multirow{14}{*}{ m-TEC } & \multirow{14}{*}{ Enterobacteriales } & Citrobacter freundii & 99 & KC835088 & 1 \\
\hline & & Enterobacter cloacae & 98 & KJ769195 & 1 \\
\hline & & Escherichia coli & 99 & СР005998 & 1 \\
\hline & & & $99-100$ & СР009106 & 2 \\
\hline & & & 99 & KJ803894 & 1 \\
\hline & & & $99-100$ & KJ803897 & 6 \\
\hline & & & 99 & KJ803899 & 1 \\
\hline & & & 100 & KJ769198 & 1 \\
\hline & & & 99 & КС924832 & 1 \\
\hline & & & 99 & JX096398 & 1 \\
\hline & & Escherichia fergusonii & 99 & HQ214033 & 1 \\
\hline & & Klebsiella pneumoniae & 99 & GQ166865 & 1 \\
\hline & & & 99 & KC835115 & 1 \\
\hline & & Klebsiella sp. & 99 & AB558497 & 1 \\
\hline
\end{tabular}

\section{Discussion}

\subsection{What Is the Main Source of Fecal Pollution in Cheonggye-cheon?}

Fecal pollution of streams has been correlated with rainfall amount [15]. The overflow of untreated sewage is one of the most serious pollutants of concern for water quality [16, 17]. The sewage collecting facility (St. 10) is located at a distance of $800 \mathrm{~m}$ from St. 1 and overflow from the facility might explain the fecal pollution on rainy days. The density of $E$. coli $(63,000 \pm 1,212 \mathrm{MPN} / 100$ $\mathrm{mL}$, data not shown) at the sewage collecting facility (St. 10) on a day without rain was 60,000 times higher than the value at the St. $1(<1 \mathrm{MPN} / 100 \mathrm{~mL})$. As seen in Table 1 , the rainfall contributed to the rapid increase of all fecal indicators, consistent with the reports by others [18], especially in urbanized watersheds [19]. The overflow induced by excess rain could be a temporary source of fecal pollution in Cheonggye-cheon.
The concentration of the three fecal indicators at St. 2 was remarkably higher than at St. 1 (upstream) and St. 5 (downstream) in main stream. That higher value at St. 2 might be related to the flow of groundwater from the vicinity of a subway line which is likely to be contaminated by surface water carrying fecal contamination flowing into the main stream nearby St. 2 [4]. The densities of TC, FC, and E. coli were 7,270 $\pm 150 \mathrm{MPN} / 100 \mathrm{~mL}$, $2,723 \pm 85 \mathrm{MPN} / 100 \mathrm{~mL}$ and $191 \pm 5 \mathrm{MPN} / 100 \mathrm{~mL}$, respectively. Another important source of fecal pollution is likely the inflow of the heavily polluted tributaries, as shown by the high density of fecal indicators in the two confluent sites of the main stream (St. 3 and St. 4) and two tributary streams (St. 6 and St. 7) (Figs. $2 \mathrm{a}, 2 \mathrm{~b}$ and $2 \mathrm{c}$ ).

\subsection{The survival Trend and Growth Potential of $E$. coli}

Although it is clear that an adequate fecal indicator should not be able to reproduce outside the animal host [20], there are questions 
about the capability of E. coli to reproduce ex situ. Generally, E. coli can survive, grow and establish populations in natural environments such as freshwater [16, 21], soil and sediments [22-25], especially in the presence of aggregates consisting of plankton and fungi $[16,26]$. In agreement with the previous reports, the E. coli attached to algae (Spirogyra sp.), the roots and stems of macrophyte (Phragmites sp.), and to sediment represented relatively high density. Furthermore, the results of the in situ growth potential test showed the density of $E$. coli to be higher with the algae supplement ( $p=0.002)$ than without ( $p=0.101$ ) (Fig. 3). Therefore, our results suggest that fecal indicators may proliferate if the indicator organisms are attached to a nutrient-enriched environment such as algae aggregates in a shallow stream like Cheonggye-cheon. However, the free living E. coli without algae present did not proliferate. More precise studies are needed to understand if the growth potential of $E$. coli in the stream is so large that the microbial water quality could be deteriorated considerably.

Next, we considered the origins of attached E. coli on algae and/or macrophytes and the steady presence of $E$. coli in the upstream of Cheonggye-cheon. It can be assumed that the $E$. coli from the sewage collecting facility via a floodgate and non-point fecal source pollutant might migrate readily into Cheonggye-cheon by heavy rainfall, then allowing it to become attached, survived and proliferated rapidly as previously reported [27]. The diverse living or dead algae and macrophytes, including their exudates, and sediment can function as a nutrient supply for the growth of E. coli [28-32]. Rainfall events will provide enough $E$. coli or other microbes to settle and colonize various materials. The episodic re-suspension due to rain events might release large numbers of $E$. coli into the stream [33, 34]. In addition, attached $E$. coli could be separated by physical agitation and/or rapid flow velocity of upstream from detached patches of algae with air bubbles by photosynthesis. This process also could be a minor cause of the increase in the number of $E$. coli in the upstream area of Cheonggye-cheon.

\subsection{What Is the Best Fecal Indicator for Evaluating Microbial Water Quality in Cheonggye-cheon?}

When considering the results of analysis of the presumptive TC, FC and E. coli evaluated by the most probable number (MPN) method using the Colilert-18 system (IDEXX, Ludwigsburg, Germany), it is apparent that there was a large fluctuation in the number of TC followed by the number of FC, compared to $E$. coli. TC has been used as a fecal indicator to assess fecal pollution for more than 100 years [22]. However, problems with using TC as a fecal indicator have been reported by many studies [10, 13-14, 35]. The genera belonging to the total coliform group such as Enterobacter sp., Citrobacter sp., Klebsiella sp., and Serratia sp. are not always associated with fecal contamination [10-11, 13]. In addition, overgrowth phenomenon by background colonies on its isolation agar, especially in warm water, indicates its limited use as fecal indicator [13, 35]. Due to this reason, the results based on TC could lead to false conclusions about fecal contamination [13, 14].

When monitoring microbial water quality using FC, thermotoler- ant coliforms [12, 36] isolated at $44.5^{\circ} \mathrm{C}$ for growth, ambiguous results might be obtained even though a larger portion of the presumptive FC were confirmed as E. coli compared to TC [13, 14]. Fiello et al (2014) surveyed recreational waters in the Mississippi River and found that only $48 \%$ of the presumptive FC colonies on m-FC agar were E. coli and postulated that the detection of FC was not sufficient to determine the actual fecal contamination of recreational water supplies [37]. Recently, the use of $E$. coli as satisfactory evidence of fecal contamination has tended to increase $[10,11]$ and $E$. coli is considered as a more reliable indicator of fecal pollution than other fecal coliforms [38].

The result of this study agrees well with the result from another study [10]. No colonies from 10 presumptive TC colonies and only 2 colonies from 20 presumptive FC colonies were closely related to $E$. coli based on analysis of the $16 \mathrm{~S}$ rRNA sequences for checking the accuracy of the presumptive TC, FC and E. coli. However, 14 colonies of 20 presumptive E. coli colonies on m-TEC were assessed as E. coli (Table 2).

In addition, many studies have shown that the concentration of E. coli and Enterococcus were positively correlated with the incidence of bather illness, while TC did not correlate well [9, 39]. Therefore, the method employed for monitoring microbial water quality should be evaluated for relevance before use. If the microbiological water quality of a small urban stream like Cheonggye-cheon is measured using TC and FC, these methods are likely to underestimate the quality of the water. In Korea, TC and FC have been used as fecal indicators for checking the quality of streams. Cheonggye-cheon functions as a recreational water, more attention should be given to concerns about human health. Therefore, we suggest the detection of $E$. coli rather than TC or FC. Enumeration of $E$. coli is urgently needed for monitoring microbial water quality in Cheonggye-cheon. An advanced method, the Colilert-18 system, was recently developed as more rapid, specific and simple identification method for the detection of $E$. coli than traditional methods [40-42], based on the presence or absence of $\beta$-glucuronidase. The false positive rate of this method is lower than the rate determined using the traditional membrane filtration method [43]. Some researchers clarified that the Colilert-18 system yields similar results with the traditional methods for detecting the presence of E. coli and coliforms (TC or FC) in freshwater [10, 41-42], and in potable water [44]. Further, this enzyme was revealed to be present in more than $95 \%$ of all E. coli isolates tested [39]. We suggest that this new method might be suitable for monitoring microbial water quality in Cheonggye-cheon.

\subsection{Suggestion for Managing the Water Quality of Small Urban Streams}

The restoration of Cheonggye-cheon stream was carried out not only for its recreational use, but also for sustaining its ecological function. Even though the stream is vulnerable to pollution, many visitors use Cheonggy-cheon as a recreational stream. Thus, a cautious approach to water quality management is needed. We suggest that Cheonggye-cheon can be divided into two sections for management purposes, a recreational area and a conservation area. In the recreational area, recreational water activities such 
as wading and/or splashing would be allowed but would be prohibited in the conservation area. Based on our results, the upstream region ensuring safety of the recreational water quality, a short distance from St. 1 to the region $0.98 \mathrm{~km}$ downwards (Fig. 1) can be designated as a recreational area. However, if problems such as temporary overflow of untreated sewage and inflow of contaminated ground water can be solved, then the recreational area could be extended up to the confluence of the tributary stream (St. 6, Seongbuk-cheon), at a distance of $5 \mathrm{~km}$. The remaining region of the stream should be managed as a conservation area. As part of the water quality management strategy, visitation should be prohibited during and following heavy rain, because this is when the microbial water quality is impaired (Table 1). Additionally, we suggest the more rigorous counter-action to intercept the inflow from the sewage facility and less rigorous counter action would be needed to monitor and to improve the water quality of the tributary streams by various implementation such as removal of fecal pollutant source.

\section{Conclusions}

The main factors which impair the microbial water quality in Cheonggye-cheon are the inflows from the two tributary streams, St. 6 and St. 7, with a high density of fecal indicators and the inflow of groundwater in the vicinity of a subway line, which is contaminated by unknown surface water at St. 2. In addition, the overflow of sewage from the sewage collection facility via the floodgate at times of heavy rain into Cheonggye-cheon stream is important as a temporary source of contamination, which subsequently allows bacterial populations to attach to algae, aquatic plants, and sediment, where they can survive for longer periods and could proliferate under optimal conditions. These attached fecal indicators can also be detached due to sheer force induced by increased stream discharge, which might raise the total number of fecal indicator bacteria in Cheonggye-cheon. Further studies are required to establish an appropriate standard based on the density of E. coli for improved management strategies for microbial water quality in Cheonggye-cheon. A water quality management plan incorporating the results from this study should be implemented to protect human health in visitors to Cheonggye-cheon stream.

\section{Acknowledgements}

This study was supported by Kangwon National University and Daegu University Research Grant 2012. We thank J. S. Owen for proofreading the manuscript.

\section{References}

1. Cho KK. The history and future of Cheonggye-cheon that flows again. Kor. Soc. Civil Eng. 2005;53:98-110.

2. Song DY. Spatial morphology and its socio-economic im- plication in Seoul's Cheonggycheon area. Eco. 2003;4:166-190.

3. Jang YK. Study on the impact of Cheonggyecheon restoration on property values [dissertation]. Seoul: Univ. of Hongik; 2013.

4. Seoul Metropolitan facilities Management Corporation. Cheonggeycheon water quality management method and academic investigation. Seoul: Seoul Metropolitan facilities Management Corporation; 2012.

5. Park Y, Lee H, Kim S, Ko GP. Assessment of fecal pollution and bacterial community structure in restored section of Cheonggyecheon stream. J. Kor. Soc. Water Qual. 2009;25:76-83.

6. Stumpf CH, Piehler MF, Thompson S, Noble RT. Loading of fecal indicator bacteria in North Carolina tidal creek headwaters: Hydrographic patterns and terrestrial runoff relationships. Wat. Res. 2010;44:4704-4715.

7. Nagels J, Davies-Colley R, Donnison A, Muirhead R. Faecal contamination over flood events in a pastoral agricultural stream in New Zealand. Water Sci. Technol. 2002;45:45-52.

8. Howard I, Espigares E, Lardelli P, Martín JL. Espigares M. Evaluation of microbiological and physicochemical indicators for wastewater treatment. Environ. Toxicol. 2004;19:241-249.

9. Cabelli VJ, Dufour AP, McCabe LJ, Levin MA. A marine recreational water quality criterion consistent with indicator concepts and risk analysis. J. Water Pollut. Control Fed. 1983;55:1306-1314.

10. Edberg S, Rice EW, Karlin RJ, Allen MJ. Escherichia coli: The best biological drinking water indicator for public health protection. J. Appl. Microbiol. 2000;88:106S-116S.

11. Fiello M, Mikell AT Jr, Moore MT, Cooper CM. Variability in the characterization of total coliforms, fecal coliforms and Escherichia coli in recreational water supplies of north Mississippi, USA. Bull. Environ. Contam. Toxicol. 2014;93:133-137.

12. USEPA. Method 1603: Escherichia coli in water by membrane filtration using modified membrane-Thermotolerant Escherichia coli Agar (Modified m-TEC). Pennsylvania: U.S. Environmental Protection Agency; 2006.

13. Lee YO. Comparative studies on detection of E. coli in surface water. Kor. J. Limnol. 1996;29:313-321.

14. Park J, Ahn T, Lee H, Lee Y. Comparison of total and faecal coliforms as faecal indicator in eutrophicated surface water. Water Sci. Technol. 2006;54:185-190.

15. McDonald A, Kay D. Enteric bacterial concentrations in reservoir feeder streams: Baseflow characteristics and response to hydrograph events. Water Res. 1981;15:961-968.

16. Byappanahalli MN, Shively DA, Nevers MB, Sadowsky MJ, Whitman RL. Growth and survival of Escherichia coli and Enterococci populations in the macro-alga Cladophora (Chlorophyta). FEMS Microbiol. Ecol. 2003;46:203-211.

17. Kacar A, Gungor F. Comparison of fecal coliform bacteria before and after wastewater treatment plant in the Izmir Bay (Eastern Aegean Sea). Environ. Monit. Assess. 2010;162:355-363.

18. Little J, Saffran KA, Fent L. Land use and water quality relationships in the lower little bow river watershed, Alberta, Canada. Water Qual. Res. J. Can. 2003;38:563-584.

19. Cho KH, Cha SM, Kang J-H, et al. Meteorological effects on the levels of fecal indicator bacteria in an urban stream: A modeling approach. Water Res. 2010;44:2189-2202.

20. Field KG, Samadpour M. Fecal source tracking, the indicator 
paradigm, and managing water quality. Water Res. 2007;41: 3517-3538.

21. Power ML, Littlefield-Wyer J, Gordon DM, Veal DA, Slade MB. Phenotypic and genotypic characterization of encapsulated Escherichia coli isolated from blooms in two Australian lakes. Environ. Microbiol. 2005;7:631-640.

22. Kavka G. Zur Frage der Nachweisbarkeit und Überlebenszeit von Kolibakterien in verschiedenen Biotopen [dissertation]. Vienna: Univ. of Vienna; 1978.

23. Anderson KL, Whitlock JE, Harwood VJ. Persistence and differential survival of fecal indicator bacteria in subtropical waters and sediments. Appl. Environ. Microbiol. 2005;71: 3041-3048.

24. Fujioka R, Sian-Denton C, Borja M, Castro J, Morphew K. Soil: The environmental source of Escherichia coli and Enterococci in Guam's streams. J. Appl. Microbiol. 1998;85:83S-89S.

25. Solo-Gabriele HM, Wolfert MA, Desmarais TR, Palmer CJ. Sources of Escherichia coli in a coastal subtropical environment. Appl. Environ. Microbiol. 2000;66:230-237.

26. Ksoll WB, Ishii S, Sadowsky MJ, Hicks RE. Presence and sources of fecal coliform bacteria in epilithic periphyton communities of Lake Superior. Appl. Environ. Microbiol. 2007;73:3771-3778.

27. Badgley BD, Thomas FIM, Harwood VJ. Quantifying environmental reservoirs of fecal indicator bacteria associated with sediment and submerged aquatic vegetation. Environ. Microbiol. 2011;13:932-942.

28. Davies CM, Long JA, Donald M, Ashbolt NJ. Survival of fecal microorganisms in marine and freshwater sediments. Appl. Environ. Microbiol. 1995;61:1888-1896.

29. Byappanahalli MN, Fujioka RS. Evidence that tropical soil environment can support the growth of Escherichia coli. Water Sci. Technol. 1998;38:171-174.

30. Harwood VJ, Butler J, Parrish D, Wagner V. Isolation of fecal coliform bacteria from the diamondback terrapin (Malaclemys terrapin centrata). Appl. Environ. Microbiol. 1999;65: 865-867.

31. Desmarais TR, Solo-Gabriele HM, Palmer CJ. Influence of soil on fecal indicator organisms in a tidally influenced subtropical environment. Appl. Environ. Microbiol. 2002;68:1165-1172.

32. Dixit SM, Gordon DM, Wu X-Y, Chapman T, Kailasapathy K, Chin JJC. Diversity analysis of commensal porcine Escherichia coli-associations between genotypes and habitat in the porcine gastrointestinal tract. Microbiol. 2004;150:1735-1740.

33. Kim JW, Pachepsky YA, Shelton DR, Coppock C. Effect of streambed bacterial release on E. coli concentration: Monitoring and modeling with the modified SWAT. Ecol. Model. 2010;221:
1592-1604.

34. Pachepsky YA, Shelton DR. Escherichia coli and fecal coliforms in freshwater and estuarine sediments. Crit. Rev. Env. Sci. Technol. 2011;41:1067-1110.

35. Lavoie MC. Identification of strains isolated as total and fecal coliforms and comparison of both groups as indicators of fecal pollution in tropical climates. Can. J. Microbiol. 1983;29: 689-693.

36. ISO (International standard). Water quality-Detection and enumeration of coliform organisms, thermotolerant coliforms organisms and presumptive E. coli Part 2 Multiple tube method. 9308-2-1990. Geneva: ISO; 1990.

37. Fiello M, Mikell AT Jr, Moore MT, Cooper CM. Variability in the characterization of total coliforms, fecal coliforms and Escherichia coli in recreational water supplies of north Mississippi, USA. Bull. Environ. Contam. Toxicol. 2014;93: 133-137.

38. Odonkor ST, Ampofo JK. Escherichia coli as an indicator of bacteriological quality of water: an overview. Microbiol. Res. 2013;4:5-11.

39. Noble RT, Moore DF, Leecaster MK, McGee CD, Weisberg SB. Comparison of total coliform, fecal coliform, and enterococcus bacterial indicator response for ocean recreational water quality testing. Water Res. 2003;37:1637-1643.

40. Chao WL. Evaluation of colilert-18 for the detection of coliforms and Escherichia coli in tropical fresh water. Lett. Appl. Microbiol. 2006;42:115-120.

41. Fricker EJ, Illingworth KS, Fricker CR. Use of two formulations of Colilert and quantitray for assessment of the bacteriological quality of water. Water Res. 1997;31:2495-2499.

42. Eckner KF. Comparison of membrane filtration and multiple-tube fermentation by the Colilert and Enterolert methods for detection of waterborne coliform bacteria, Escherichia coli, and Enterococci used in drinking and bathing water quality monitoring in southern Sweden. Appl. Environ. Microbiol. 1998;64:3079-3083.

43. Pisciotta JM, Rath DF, Stanek PA, Flanery DM, Harwood VJ. Marine bacteria cause false-positive results in the Colilert-18 rapid identification test for Escherichia coli in Florida waters. Appl. Environ. Microbiol. 2002;68:539-544.

44. Rice EW, Allen MJ, Edberg SC. Efficacy of beta-glucuronidase assay for identification of Escherichia coli by the defined-substrate technology. Appl. Environ. Microbiol. 1990;56:1203-1205. 